\title{
An Assessment of Drought in Mannar District, Sri Lanka
}

\author{
Dr. K. Rajendram \\ Department of Geography \\ Eastern University \\ Vantharumoolai \\ Chenkalady,30350, Sri Lanka \\ Email: rajendramk@esn.ac.lk
}

Sri Lanka

\section{ABSTRACT}

Due to recent climate changes and variability the frequency of occurrence and intensity of extreme climatic events such as flood, drought, etc. are increasing significantly in Sri Lanka. The main objectives of the study are to analyze the annual and seasonal rainfall variability in the last 147years from 1871-2018 with particular reference to drought and to assess the occurrence of droughts and its intensity and the impacts of drought on agriculture. For this secondary and primary data have been used. The long-term average annual rainfall of Mannar show the decreasing trend $\left(r^{2}=0.0158\right)$, particularly in recent epochs higher negative anomalies of rainfall were found, as a results frequent occurrence of droughts or dry spells have been occurred. The rainfall anomaly results reveal that, out of 147years of the data period about $47 y e a r s$ were experienced as drought and its probability is $P=0.320$. Accordingly, once in four to five years a drought could be possible. However, in the recent epoch of 1991-2018, higher number of droughts occurred than the any other epochs and its epochal probability is higher $(P=0.40)$ than the normal, which indicate the effect of recent climate change.

\section{Keywords: Drought Intensity, Rainfall Variability, Impact of Drought, Climate Change}

\section{Introduction}

Drought is a natural phenomenon that usually associated with a deficiency of rainfall from normal or expected amounts over an extended period of time. It occurs in many regions of the world every year, with serious damage to national economic structures, especially water resource, agriculture, and cattle breeding sector (Cabrinha and Santo, 2000). Drought is a deficiency in precipitation over an extended period, usually a season or more, resulting in a water shortage causing adverse impacts on vegetation, animals, and/or people. It is a normal, recurrent feature of climate that occurs in virtually all climate zones, from very wet to very dry (National Drought Mitigation Center U.S., 2008). The economic, social and environmental costs and losses associated with drought (Wilhite and Mark Svoboda, 2000). Drought means various things to various people, depending on their specific interest. To the farmers, drought means a shortage of moisture in the root zone of crops. To the hydrologist it suggests below average water levels in streams, lakes and reservoirs. To the economist, it means a water shortage which adversely affects the established economy. Each has concern which depends on the effects of a fairly prolonged weather anomaly (Palmer,1965). Drought is universally recognized as a phenomenon associated with scarcity of water; they are recurring features of the climate. Drought varies with regard to the time of occurrence, duration, intensity, and extent of the area affected from year to year. It is broadly classified in to four categories such as meteorological drought, hydrological drought, agricultural drought and socio-economic drought. Meteorological drought indicates the deficiency of rainfall compared to normal rainfall in a given region. Hydrological drought indicates the scarcity water in a surface and underground resources. Agricultural drought occurs when the rainfall and soil are inadequate to meet the water requirements of crops and socio-economic drought that express the features of socio-economic effects of drought can also incorporate features of meteorological, agriculture, and hydrological drought (Subrahmanyam, 1967, Wilhite and Michael, 1987, Sinha Ray, 2000). Sri Lanka is located in the tropical region, has experienced cyclical droughts of high intensity, occurring in intervals of three to four years. These droughts have had a series of adverse impacts on the economic and social life of people in the country. In recent decades, droughts caused the biggest damage to the country's agriculture (Prasanna, 2018). The frequent occurrence of droughts and dry spells has been experiencing mainly in the dry zone of 
Sri Lanka especially in the north western part of Sri Lanka represented by meteorological station-Mannar. The availability of surface water in the country particularly in the dry zone is frequently affected by the failure of monsoon resulting in prolonged drought. Sri Lanka's economy primarily depends on agriculture. More than two third of the country comes under dry zone which experiences frequent water problem. The study area is located in north western part of the dry zone and receives less rainfall $(976 \mathrm{~mm})$ compare with other regions in Sri Lanka. Due to wide range of climatic fluctuation, the natural phenomena such as drought and flood do occur and affect not only farming but also other activities. For example, from the second half of the twentieth century, catastrophic droughts occurred in Sri Lanka in the years of 2019, 2018, 2016, 2017, 2004, 2001,1997, 1995-96, 1992, 1988, 1980-83, 1974-76, 1960 and 1950.

According to situation report released by the ministry of disaster management in October 2019, about 195685 families and 694457 persons were affected by drought in Sri Lanka which spread over mainly in the Northern, North western, Central, North central, Subaragamuwa, Uva and Southern provinces. The district of Mannar comes under Northern Province which severely affected by drought in 2019 about 18074 families and 63115 persons were affected. Average annual rainfall of the study area is $976 \mathrm{~mm}$, since about 73 percent of rainfall receives from second and North East monsoon seasons.

The Disaster Management Center (DMC) stated that up to 890,000 persons were affected by drought across the country in 2018. The districts of Puttalam, Anuradhapura, Mannar, and Mulaithivu were the worst affected. State Minister reported that the measures have been taken to distribute water to 89 of the worst affected divisional secretariats and about 58.3 million rupees has been allocated for mitigation purpose. The Irrigation Department reported that the water capacity of the 72 reservoirs under its purview have decreased to 35percent of its total capacity. In 2019, drought continued which spread more than seventeen districts in Sri Lanka, according to the ministry of disaster management reported (October 2019) about 694457 persons were affected. The district wise affected families are shown in Table-I.

Table-1: Drought Affected Families in Sri Lanka, October-2019

\begin{tabular}{|l|r|r|l|r|r|}
\hline District & \multicolumn{1}{|l|}{ Families } & Person & District & Families & \multicolumn{1}{l|}{ Person } \\
\hline Ratnapura & 723 & 2749 & Kandy & 5455 & 20328 \\
\hline Puttalam & 12109 & 39274 & Hambantota & 2149 & 9316 \\
\hline Kurunegala & 14266 & 45496 & Polonnaruwa & 8587 & 28734 \\
\hline Vavuniya & 759 & 2578 & Anuradhapura & 9639 & 35821 \\
\hline Jaffna & 21094 & 70628 & Ampara & 11536 & 69957 \\
\hline Mannar & 18074 & 63115 & Trincomalee & 4197 & 13150 \\
\hline Kilinochchi & 9933 & 34785 & Batticaloa & 26078 & 86635 \\
\hline Mullaitivu & 18812 & 61154 & Moneragala & 17142 & 57576 \\
\hline Matale & 15132 & 53161 & & & \\
\hline
\end{tabular}

Source: Disaster Management Centre, October, 2019

Spatial extent and temporal evaluation drought in Sri Lanka specially one of the droughts affected districts of Polonnaruwa (during 2016-2017) have been studied (Ruchira Lokuhettilet.al.,2017). Study stated, Sri Lanka experienced a severe drought in 2016/17 punctuated by a deluge of rain in May. Part of the Yala season of 2016 (June to September) and Maha season of 2016/17 (October to March) was affected by the drought. The total water capacities at 73 major reservoirs were reported at 29\%. During this Maha season 612,223 hectares of paddy was cultivated of which 50,615 hectares was damaged due to the drought and it amounts to a loss of 4, 053,395 bushels of paddy. According to the Disaster Management Center, 1.8 million people across 20 districts were affected as of September 2017. The nature of drought, perception of the people about drought impacts and adaptation strategies used by the people in North Central Province (NCP) was examined (Gunawardhana and Lal Mervin Dharmasiri, 2015). The results highlighted that there are so many traditional droughts forecasting and adaptation strategies are being 
used by the farmers to cope with drought impacts where both on farm and off farm strategies are used. The Food and Agricultural Organization (FAO) and the United Nations World Food Programme (WFP) reported that, a severe drought followed in Sri Lanka in 2016 \& 2017, has hit large swaths of cropping areas, threatening the food security of some 900,000 people. According to the joint Crop and Food Security Assessment Mission, drought condition in 2016 and early 2017led to widespread crop failures, in particular for paddy crop- the country's staple food. Total paddy production forecast in 2017 is 2.7 million tones, almost $40 \%$ less than the last year's output and $35 \%$ lower than the average of the previous five years. Other crops, including various pulses, chilies and onion, which rely mainly on rainwater, were also heavily damaged by the dry weather (FAO\&WFP 2017). In 1980-1983, Sri Lanka experienced severe droughts, which significantly affected the paddy crop, ecosystem and water supply. In the 198183drought, 925,666 persons were affected and relief expenditure was Rs.427 million. In 1996, 775,000 persons were affected and the expenditure on relief amounted to Rs.425 million. Moreover, in the year of 2001 drought has severely affected more than 64 percent area of the country. The Department of Social Services reported on $19^{\text {st }}$ February 2002, about 1,621,986 persons and 370,541 families were affected which spread over in six districts of Kurunegala (352,380), Ratnapura (245,688), Puttalam (167,172), Monaragala (287,005), Badulla (102,851) and Ampara (62,516) (Revised Record, Department of Social Service, February 2002). The Government of Sri Lanka and Sri Lankan Red Cross Society (SLRCS) had requested (on15 ${ }^{\text {th }}$ August 2001) for foreign aids to mitigate the great losses of farmers. Particularly the shortage of water affects repeatedly in agriculture, drinking water supply and ecosystem.

The dry zone is generally characterized by the occurrence of effective dry periods and the wet zone does not experience long dry spells (Wikkramatileke 1963, Domros, 1974). A few attempts have been made to study the pattern of drought occurrence in Sri Lanka employing a variety of techniques of analysis and methodology. Since the early thirties of the present century when the country suffered from drought due to inconsistence of monsoon activities, scholars have paid attention to monsoon rainfall fluctuation and drought studies. The problem of droughts has been examined from different angles, particularly in the context of lack of rainfall during the monsoon season either on account of late start or early withdrawal or both, and irregular in inadequate distribution of rainfall during the season. Domros (1978) had studied on drought based on ninety years observation (1875-1964) he pointed out that the most frequent drought months occur during the Southwest monsoon season and also that all stations of the dry zone were characterized by a great frequency of drought months. Balachandiran (1975) examined the meteorological drought based on the monthly rainfall analysis throughout Sri Lanka for the period of 23 years (1948-1970), and he categorized the drought according to negative departure from the normal rainfall. Based on the water balance method Sirinanda (1975) had examined the dry zone drought. This article was analyzed in accordance with the data of temperature and rainfall for 30 years period (1931-60). Effect of 1981 drought on peasant families' economy in Mahapotana Korale division (north central province) had studied by Madduma Bandara (1983). Tennakoon (1993) made a study on drought. This study mainly focused on how the farmers perceive drought and adjust to it in the Anuradhapura district. Frequent occurrence of drought as well as inadequate research in regional levels have emphasized need for more research on the intensity as well as its impacts which could help for an appropriate planning to mitigate the possible worst effects in future drought.

\section{Study Area}

The district of Mannar is located in the north western part of dry zone of Sri Lanka and consists of an island and other part of the district is surrounded by the districts of Vavuniya, Anuradhapura, Puttalam, Kilinochchi and Mullaitivu. The area of the district is 2,002 Sq.km. Total population of the district is 161, 604 (2015). There are five divisional secretariats divisions namely Madhu, Mannar-Town, Manthai-west, Musali and Nanattan (Fig.1). About 622 villages are administered by 153 Grama Niladharies divisions.

The main livelihood activities in the district are agriculture, fishing and animal-husbandry. About $70 \%$ of the population involves in agriculture mainly in paddy cultivation, another $25 \%$ do fishing and remaining $5 \%$ of them involve in other occupations (Statistical Branch 2019). The second longest river of Aruviyaru in Sri Lanka runs through the districts of Anuradhapura and Mannar. The thekkam-bund was constructed across the Malwathu-Oya and water flows through two canals, one to the Giant-tank in Murunkan and other to the Ahaththimurippukulam. Since 


\section{E-ISSN: 2471-7576}

November 2019, Vol: 4, Issue: 11

E-mail: editor@ijhassnet.com

http://ijhassnet.com/

DOI: 10.33642/ijhass.v4n11p1

(C) Center for Promoting Education and Research (CPER) USA, www.cpernet.org

the year 1969 the Giants tank has been maintained by the department of irrigation. The water for this tank comes through Aruviyaru that is 16.24 miles in length. The capacity of the tank is 31,500 acre/ feet and nearly 30,000 acres of paddy-fields are being irrigated from it. There are ten sluices at this tank; water has been send to smaller ponds from Viyathikkulam and Ahaththimurippukulam.

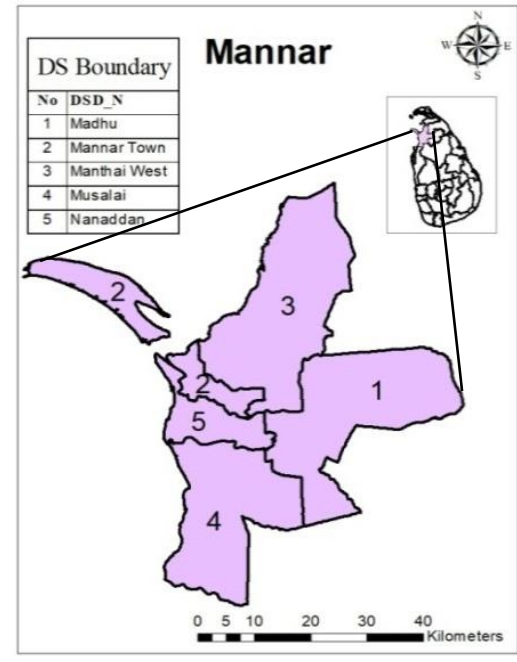

Fig.1 Location of Study Area

\section{Materials and Methods}

Required data for this study have been collected from available secondary and primary sources. Long term monthly and annual rainfall data for 147 years period from 1871 to 2018 for the Mannar and Murunkan stations has been collected from the Department of Meteorology, Colombo and the Department of Irrigation. To study the epochal intra-annual variability in particular reference to drought, rainfall data has been categorized as different epochs and then its standard deviation (SD) and Co-efficient of variation (CV), least square trend have been computed for different epochs.

McKee et al. (1993) developed the Standardized Precipitation Index (SPI) to monitor the status of drought in Colorado. The SPI is a powerful, flexible index that is easy to compute. In fact, precipitation is the required input parameter to monitor the drought, flood and intra-seasonal rainfall anomaly. In addition, it is just as effective in analyzing wet and dry periods cycles. Thus, the US National Drought Mitigation Center recognized the SPI to monitor the rainfall anomaly and drought conditions. The SPI computation for any place is based on the long-term precipitation record for a chosen period. This long-term record is fitted to a probability distribution, which is then transformed into a normal distribution so that the mean SPI for the location and desired period is zero (Edwards and McKee, 1997). SPIs were suggested (Guttman, 1998) type III distribution. Gamma distribution with three parameters is given as rainfall anomaly is then studied from the normalized rainfall series in accordance with the SPI criteria (Table-II).

Table II SPI Categorization

\begin{tabular}{|l|l|}
\hline SPI value & Condition \\
\hline 2.0 or more & Extremely wet \\
\hline 1.5 to 1.99 & Very wet \\
\hline 1.0 to 1.49 & Moderately wet \\
\hline-0.99 to 0.99 & Near normal \\
\hline-1.0 to -1.49 & Moderately dry \\
\hline-1.5 to -1.99 & Severely dry \\
\hline-2 and less & Extremely dry \\
\hline
\end{tabular}

Source: Edwards and McKee, 1997 
The SPI was designed to quantify the precipitation anomaly for multiple timescales. To study the drought in this study SPI have been computed for the long-term monthly rainfall data of Mannar, Murunkan and other surrounding stations drought years have been recognized based on the following categorization given in Table-II.

To study the spatial variability of rainfall and drought interpolation techniques has been applied for SPI results and coefficient of variation of annual rainfall by using Arc GIS 10.2 software. To study the agricultural drought impacts field visits, household interviews, and focus group discussion with relevant authorities have been done. During the drought of 2016, 2017 \& 2018 district's agriculture was significantly affected due to inadequate water supply. To study the drought impacts, famers were selected using stratified random sampling method in major agricultural areas of Murunkan, Nanaddan, Silavathurai, Periyagamam and Vidataltivu villages, twenty samples in each village, out of which ten from irrigated fields another ten from rain fed farming, altogether 100 samples were selected for household interviews. Also, the secondary data on agriculture, water, soil and climate also were collected from the various Government Departments to support this study.

\section{Results}

\subsection{Rainfall and its variability}

The rainfall of Sri Lanka has considerable spatial and temporal variations that have been observed not only annually but also seasonally. Low rainfall as well as high variability is observed in the dry zone than in the wet zone of Sri Lanka. As a result of which, droughts are much more severe, frequent and widespread in the dry zone (Rajendram,2005). The long-term average annual rainfall of Mannar is 976mm; however, the significant spatial (Fig.2), temporal (Fig.3) and seasonal variations are seen in the pattern of rainfall of Mannar. The long-term annual rainfall analysis reveals that the decreasing tendency is shown in fig.3. Particularly annual rainfall has been noticeability degreasing $\left(r^{2}=0.0158\right)$ in recent years as a result there is a possibility for frequent drought or dry spells which were experienced.

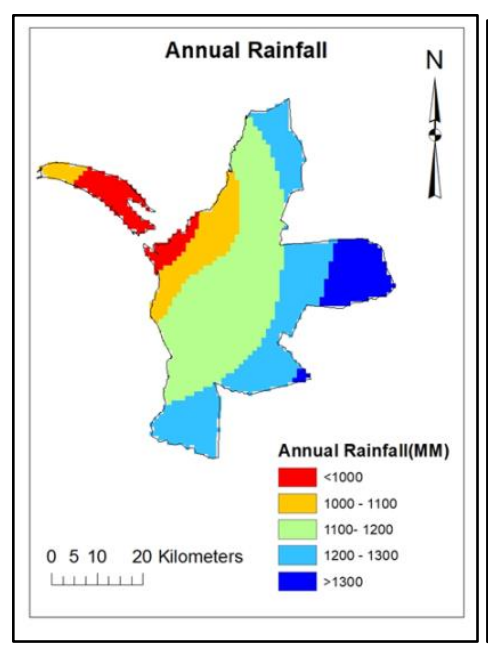

Fig.2 Annual Rainfall in Mannar

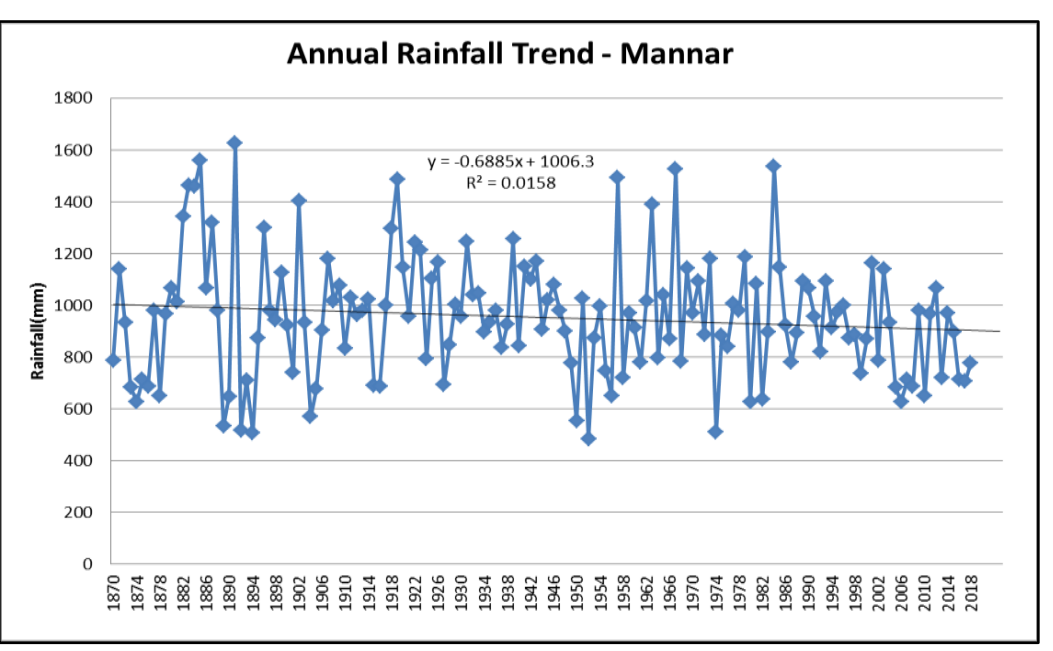

Fig.3 Annual Rainfall Trend

The Standard Deviation and Co-efficient of Variation is useful descriptive statistical parameters to study the rainfall variability of a place. These parameters indicate the amount of variability inherent in rainfall data over a long period of time from the mean value. A low ratio indicates a high degree of dependability, and high ratio indicates an erratic behavior. According to Petersen (1956), when the ratio of variability is less than 15 percent, there is a high degree of dependability. But in the areas with 20 to 25 percent variability, there is a constant fear of prolonged drought, and dependability of rainfall is minimal. All the great deserts in the world have more than 30 percent variability. The epochal rainfall and its variability are shown in table III. The Variability of rainfall was higher in the epochs of $1871-1900(\mathrm{CV}=32.6 \%)$, and $1961-1990(\mathrm{CV}=24.2 \%)$ than the others epochs. There are no any epochs noticed less than 15 percent of CV. Spatial variation of CV is ranged between 24\%-30\% which shown in Fig.4. 
International Journal of Humanities and Applied Social Science (IJHASS)

E-ISSN: 2471-7576

November 2019, Vol: 4, Issue: 11

E-mail: editor@ijhassnet.com

http://ijhassnet.com/

DOI: 10.33642/ijhass.v4n11p1

(C) Center for Promoting Education and Research (CPER) USA, www.cpernet.org

Table III Epochal Annual Rainfall and its Variability at Mannar

\begin{tabular}{|l|c|c|c|c|c|c|c|}
\hline Epochs & $\begin{array}{c}\text { Rainfall } \\
(\mathbf{m m})\end{array}$ & SD & CV (\%) & Epochs & $\begin{array}{c}\text { Rainfall } \\
(\mathbf{m m})\end{array}$ & SD & CV (\%) \\
\hline $1871-1900$ & 978.8 & 318.6 & 32.6 & $1961-1990$ & 986.4 & 238.3 & 24.2 \\
\hline $1901-1930$ & 987.7 & 223.2 & 22.6 & $1991-2018$ & 868.9 & 181.7 & 20.9 \\
\hline $1931-1960$ & 951.4 & 208.9 & 22.0 & & & & \\
\hline
\end{tabular}

\subsection{Seasonal Rainfall and its Variability}

Seasonality has a significant role in the tropical weather system. Generally, the wet zone part of Sri Lanka receives substantial rainfall during summer monsoon season or southwest monsoon (SWM) season from May to September. Concurrently the dry zone of Sri Lanka including Mannar receives rain in winter season. Seasonal rainfall is mainly concentrated in the Second Inter Monsoon (SIM- from October to November) and North East Monsoon (NEM- from December to February) seasons. About 42.7\% (418.7mm) rainfall receives in SIM during which convection, depressions of pressure, cyclonic wind circulation and convergence activity make rainfall intensify and widespread. During NEM season due to easterly air current, convection and cyclonic wind circulation, study area receives about $30.5 \%(297.2 \mathrm{~mm})$ rainfall which has a great influence upon agricultural systems and water supply. During the SWM and First Inter Monsoon (FIM-March and April) seasons the region receives about $12 \%$ in each season (Fig.5).

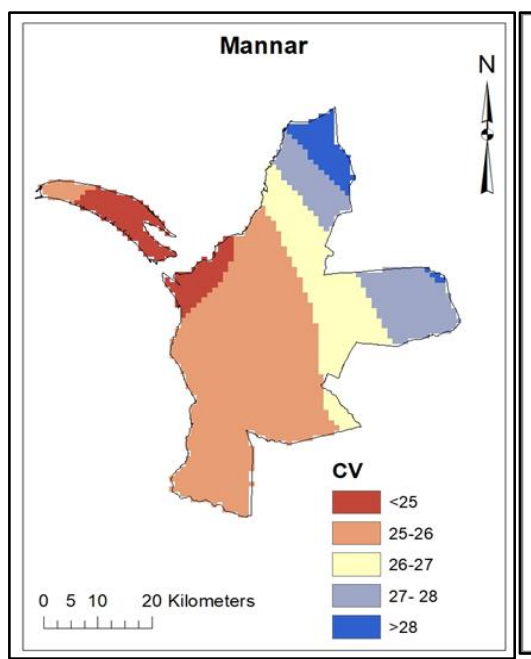

Fig.4 CV of Annual Rainfall

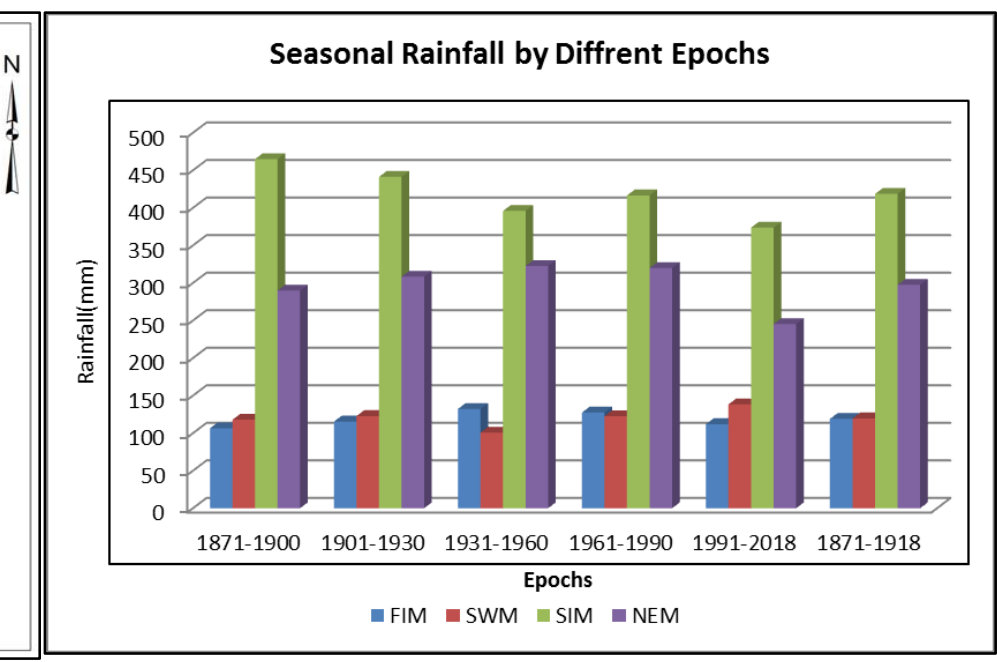

Fig.5: Seasonal Rainfall for Different Epochs

In the recent epoch of 1991-2018 the SWM and NEM rainfall decrease from the normal than in any other epochs. Moreover, more than $73 \%$ of rainfall receives in study area during SIM and NEM seasons however that rainfall of both seasons also has greater variability as well as the decreasing tendency particularly in the epoch of 1991-2018 (Fig.5 \& 6).

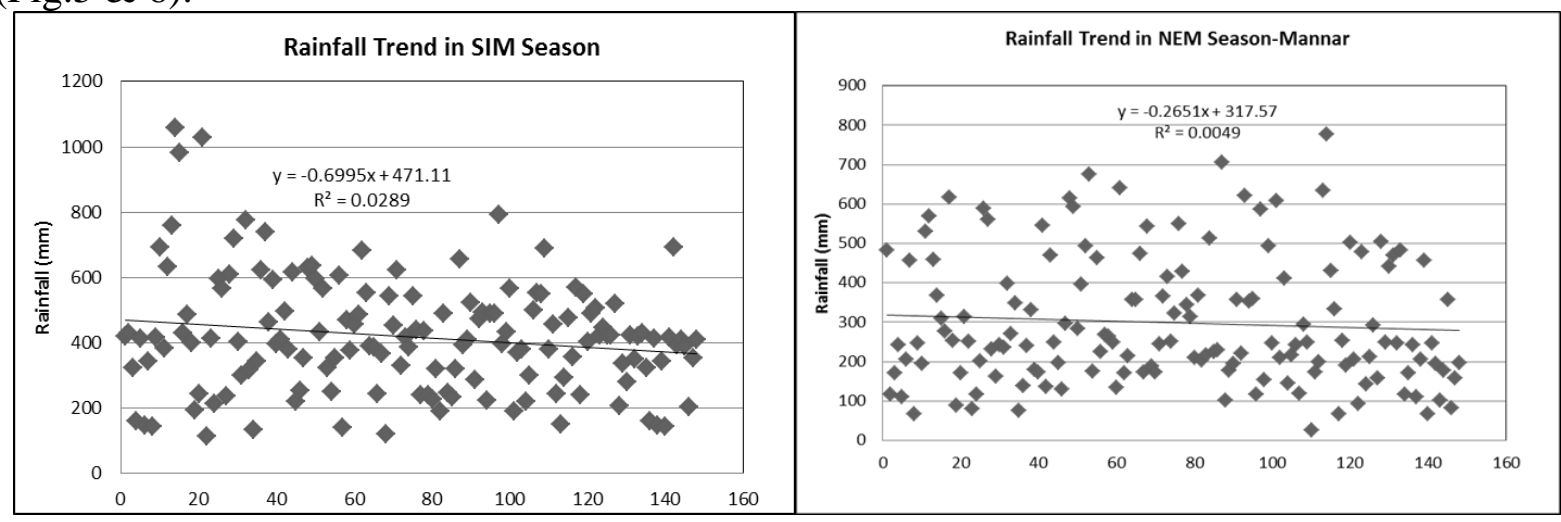

Fig. 6: Rainfall Trends in SIM and NEM seasons 
International Journal of Humanities and Applied Social Science (IJHASS)

\section{E-ISSN: 2471-7576}

November 2019, Vol: 4, Issue: 11

E-mail: editor@ijhassnet.com

http://ijhassnet.com/

DOI: 10.33642/ijhass.v4n11p1

(C) Center for Promoting Education and Research (CPER) USA, www.cpernet.org

Epocal monthly rainfall is shown in Fig.7. In the study area From the month of October to December rainfall ranges in the stydy areas receives between $153 \mathrm{~mm}$ to $263 \mathrm{~mm}$. Epochal monthly rainfall shows the deviation from the long term mean; pertuculaly from the epoch of 1991-2018 perticularly from October to December. As a results frequency of the occurrence of drought or dry spells probabilities incresed in the recent epochs.

\subsection{Occurrence of Drought \& its Intensity in Different Epochs}

The drought years and its conditions have been assessed according to the epochs. And the description is given in chronological order as 1991-2018, 1961-1990, 1931-1960, 1901-1930 and 1871-1900. The recent epoch not touched the 30 years, thereby 27 years has considered as an epoch.

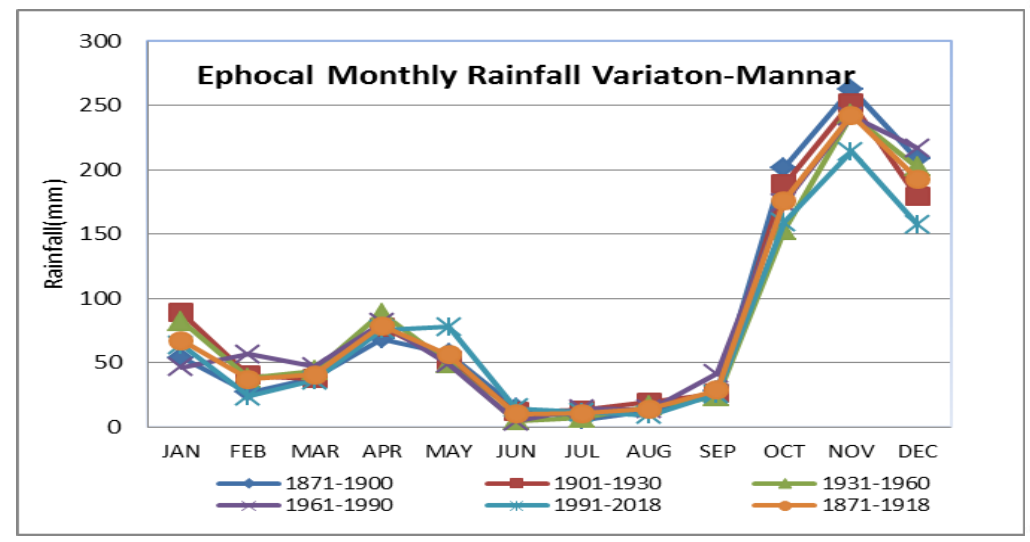

Fig. 7 Epocal Monthly Rainfall

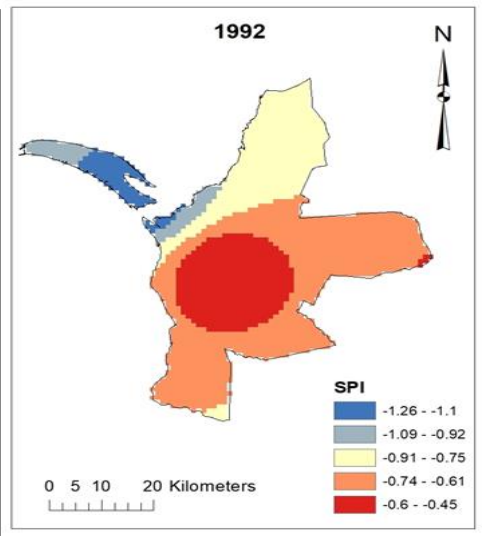

Fig. 8 Spatial Variation of SPI-1992

\subsubsection{Epoch 1991-2018}

The frequency of occurrence of occurrence of drought in the recent epoch of 1991-2018 is higher than the other all epochs. The probability of the occurrence is $\mathrm{P}=0.40$, every two to three years a drought could be occurred in this epoch. All other drought years were noticed as moderate drought (Table-IV) there weren't extreme drought or severe drought except in 2010. Spatial variation of SPI for the drought year of 1992, 1999 and 2017 is shown in Fig.9. Drought year of 1992 and 1999 the negative SPI were noticed in all over the district of Mannar. Comparatively the drought affected areas are more in 1999 drought.

Table IV: Drought Years and its Intensity-1991-2018

\begin{tabular}{|c|c|c|c|c|c|c|c|c|}
\hline $\begin{array}{c}\text { Drought } \\
\text { Years }\end{array}$ & SPI & $\begin{array}{c}\text { Drought } \\
\text { Condition }\end{array}$ & $\begin{array}{c}\text { Drought } \\
\text { Years }\end{array}$ & SPI & $\begin{array}{c}\text { Drought } \\
\text { Condition }\end{array}$ & $\begin{array}{c}\text { Drought } \\
\text { Years }\end{array}$ & SPI & $\begin{array}{c}\text { Drought } \\
\text { Condition }\end{array}$ \\
\hline 1992 & -1.26 & $\mathrm{M}$ & 2005 & -1.09 & $\mathrm{M}$ & 2010 & -1.51 & $\mathrm{~S}$ \\
\hline 1994 & -1.01 & $\mathrm{M}$ & 2006 & -1.39 & $\mathrm{M}$ & 2013 & -1.09 & $\mathrm{M}$ \\
\hline 1999 & -1.06 & $\mathrm{M}$ & 2007 & -1.13 & $\mathrm{M}$ & 2016 & -1.02 & $\mathrm{M}$ \\
\hline 2004 & -1.12 & $\mathrm{M}$ & 2008 & -1.13 & $\mathrm{M}$ & 2017 & -1.15 & $\mathrm{M}$ \\
\hline
\end{tabular}

$\mathrm{E}=$ Extreme Drought $\mathrm{S}=$ Severe Drought $\mathrm{M}=$ Moderate Drought

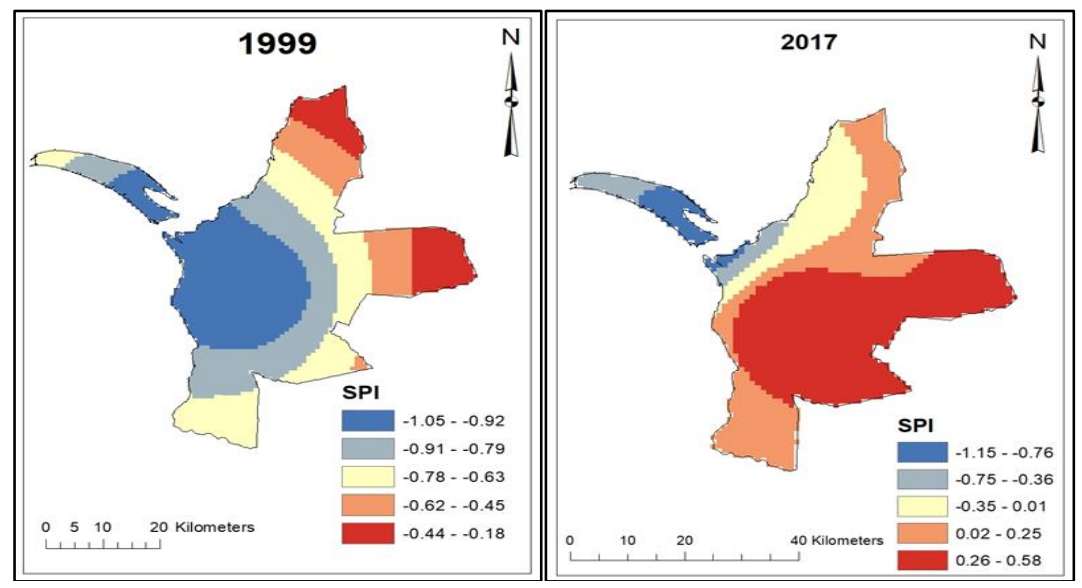

Fig.9 Spatial Variation of SPI-Mannar District 


\section{E-ISSN: 2471-7576}

November 2019, Vol: 4, Issue: 11

E-mail: editor@ijhassnet.com

http://ijhassnet.com/

DOI: 10.33642/ijhass.v4n11p1

(C)enter for Promoting Education and Research (CPER) USA, www.cpernet.org

\subsubsection{Epochs 1961-1990 \& 1931-60}

The frequency of occurrence of drought is higher in the epoch of 1961-1990 when compare with the epoch of 1931-1960. Epochal probability was $\mathrm{P}=0.27$, once in three to four years a drought could be occurred. There was an extreme drought in1974 and two severe droughts were experienced in1980, and 1982. The years 1961, 1964, 1968, 1966 \&1987 were moderate drought years. Drought years and its intensity is show Table-V. The spatial variability of SPI for the drought years of 1980, 1982 and1987 is shown in Fig. 10.

Table-V Drought Years and its intensity Epochs 1961-1990 \& 1931-1960

\begin{tabular}{|c|c|c|c|c|c|c|c|c|c|c|c|}
\hline \multicolumn{6}{|c|}{ 1961-1990 } & \multicolumn{3}{|c|}{$1931-1960$} & \multirow[b]{2}{*}{$\begin{array}{l}\text { Drought } \\
\text { Years }\end{array}$} & \multirow[b]{2}{*}{ SPI } & \multirow[b]{2}{*}{$\begin{array}{c}\text { Drought } \\
\text { Condition }\end{array}$} \\
\hline $\begin{array}{c}\text { Drought } \\
\text { Years }\end{array}$ & SPI & $\begin{array}{c}\text { Drought } \\
\text { Condition }\end{array}$ & $\begin{array}{c}\text { Drought } \\
\text { Years }\end{array}$ & SPI & $\begin{array}{c}\text { Drought } \\
\text { Condition }\end{array}$ & $\begin{array}{c}\text { Drought } \\
\text { Years }\end{array}$ & SPI & $\begin{array}{c}\text { Drought } \\
\text { Condition }\end{array}$ & & & \\
\hline 1961 & -1.08 & M & 1974 & -2.07 & E & 1949 & -1.08 & M & 1956 & -1.51 & $\mathrm{~S}$ \\
\hline 1964 & -1.02 & $\mathrm{M}$ & 1980 & -1.50 & $\mathrm{~S}$ & 1950 & -2.09 & $\mathrm{E}$ & 1958 & -1.12 & $\mathrm{M}$ \\
\hline 1968 & -1.07 & $\mathrm{M}$ & 1982 & -1.56 & $\mathrm{~S}$ & 1952 & -2.08 & $\mathrm{E}$ & & & \\
\hline 1966 & -1.11 & $\mathrm{M}$ & 1987 & -1.08 & $\mathrm{M}$ & 1955 & -1.01 & $\mathrm{M}$ & & & \\
\hline
\end{tabular}

The epoch of 1931-1960 had receive good rainfall than the subsequent epoch as a results frequency of drought years are less compare with the following epoch of 1961-1990. However, there was an extreme drought occurred in the year1950 and 1952, a severe drought prevailed in1949, 1950 \& 1956. Similarly, two moderate drought (1955, 1958 ) years were prevailed in this epoch. The probability of the drought was $\mathrm{P}=0.20$. Once in five years a drought occurred in the epoch of 1931-1960 (Table-V)
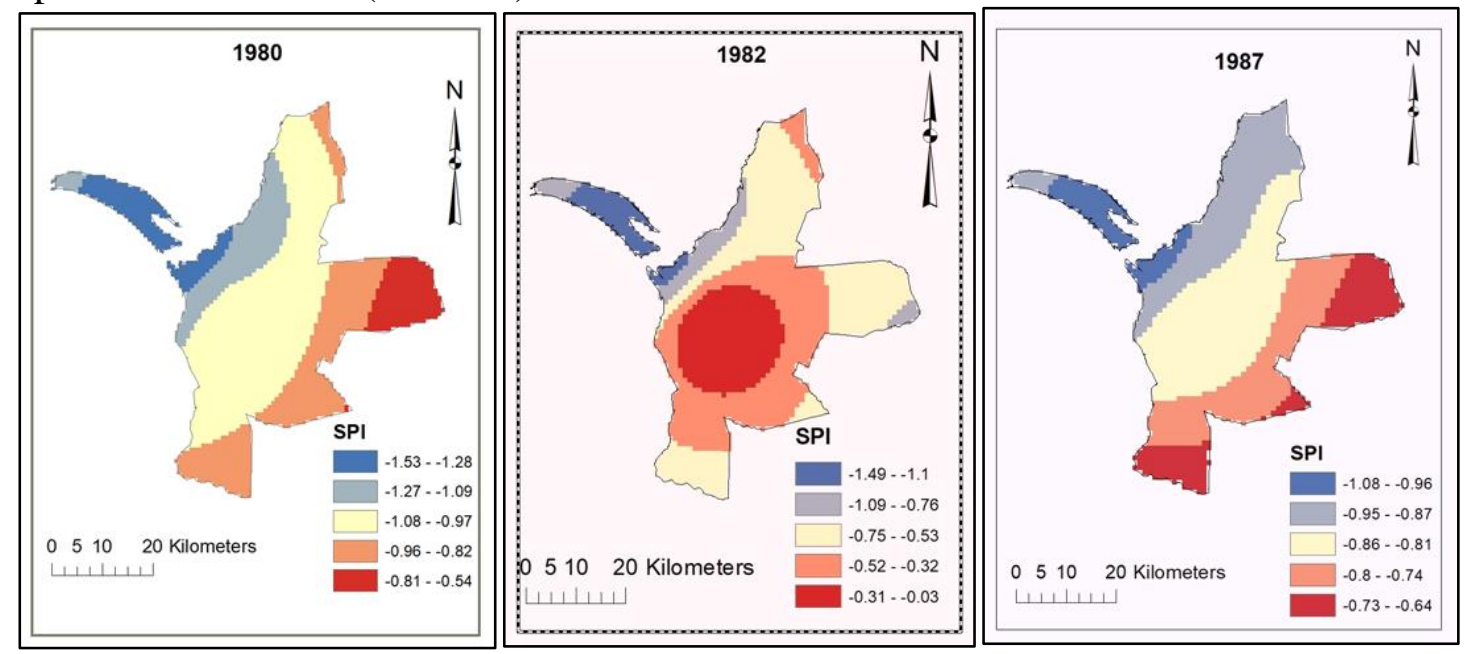

Fig.10 Spatial Variation of SPI-Mannar District

\subsubsection{Epochs 1901-1930 \& 1871-1900}

The frequencies of occurrence of droughts were higher in the epoch 1871-1900 as well as the epoch and 19011930 compare with the epoch of 1931-1960. The severe drought was experienced in the year 1904-1905 \& 1927 in the epoch of 1901-1930. Similarly, moderate droughts were noticed in 1901, 1906, 1912,1915,1916,1924 and 1930. The probability of the occurrence of the epoch of 1901-1930 is $\mathrm{P}=0.23$. In the epoch 1871-1900 there were eleven drought years, three extreme drought years had occurred in $1889,1892 \& 1894$ and one severe drought year had prevailed in 1890 (Table VI). 
E-ISSN: 2471-7576

November 2019, Vol: 4, Issue: 11

E-mail: editor@ijhassnet.com

http://ijhassnet.com/

DOI: 10.33642/ijhass.v4n11p1

(C) Center for Promoting Education and Research (CPER) USA, www.cpernet.org

Table-VI: Drought Years and its severity Epochs 1901-1930 \& 1871-1900

\begin{tabular}{|c|c|c|c|c|c|c|c|c|c|c|c|}
\hline \multicolumn{9}{|c|}{$1901-1930$} & \multicolumn{9}{c|}{$1871-1900$} \\
\hline $\begin{array}{c}\text { Drought } \\
\text { Years }\end{array}$ & SPI & $\begin{array}{c}\text { Drought } \\
\text { Condition }\end{array}$ & $\begin{array}{c}\text { Prought } \\
\text { Years }\end{array}$ & SPI & $\begin{array}{c}\text { Drought } \\
\text { Condition }\end{array}$ & $\begin{array}{c}\text { Drought } \\
\text { Years }\end{array}$ & SPI & $\begin{array}{c}\text { Drought } \\
\text { Condition }\end{array}$ & $\begin{array}{c}\text { Prought } \\
\text { Years }\end{array}$ & $\begin{array}{c}\text { Drought } \\
\text { SPI } \\
\text { Condition }\end{array}$ \\
\hline 1901 & -1.04 & $\mathrm{M}$ & 1915 & -1.24 & $\mathrm{M}$ & 1872 & -1.12 & $\mathrm{M}$ & 1878 & -1.28 & $\mathrm{M}$ \\
\hline 1904 & -1.73 & $\mathrm{~S}$ & 1916 & -1.25 & $\mathrm{M}$ & 1873 & -1.15 & $\mathrm{M}$ & 1889 & -2.08 & $\mathrm{E}$ \\
\hline 1905 & -1.50 & $\mathrm{~S}$ & 1924 & -1.03 & $\mathrm{M}$ & 1874 & -1.39 & $\mathrm{M}$ & 1890 & -1.51 & $\mathrm{~S}$ \\
\hline 1906 & -1.08 & $\mathrm{M}$ & 1927 & -1.53 & $\mathrm{~S}$ & 1875 & -1.02 & $\mathrm{M}$ & 1892 & -2.04 & $\mathrm{E}$ \\
\hline 1912 & -1.09 & $\mathrm{M}$ & 1930 & -1.00 & $\mathrm{M}$ & 1876 & -1.13 & $\mathrm{M}$ & 1893 & -1.16 & $\mathrm{M}$ \\
\hline & & & & & & & & & 1894 & -2.08 & $\mathrm{E}$ \\
\hline
\end{tabular}

E=Extreme Drought $S=$ Severe Drought $\mathrm{M}=$ Moderate Drought

The epochal probability of occurrence is $\mathrm{P}=0.37$. Once in three years a drought had occurred in this epoch. The annual rainfall anomaly from the period from 1871-2018 is shown in Fig.11which depicts the variability.

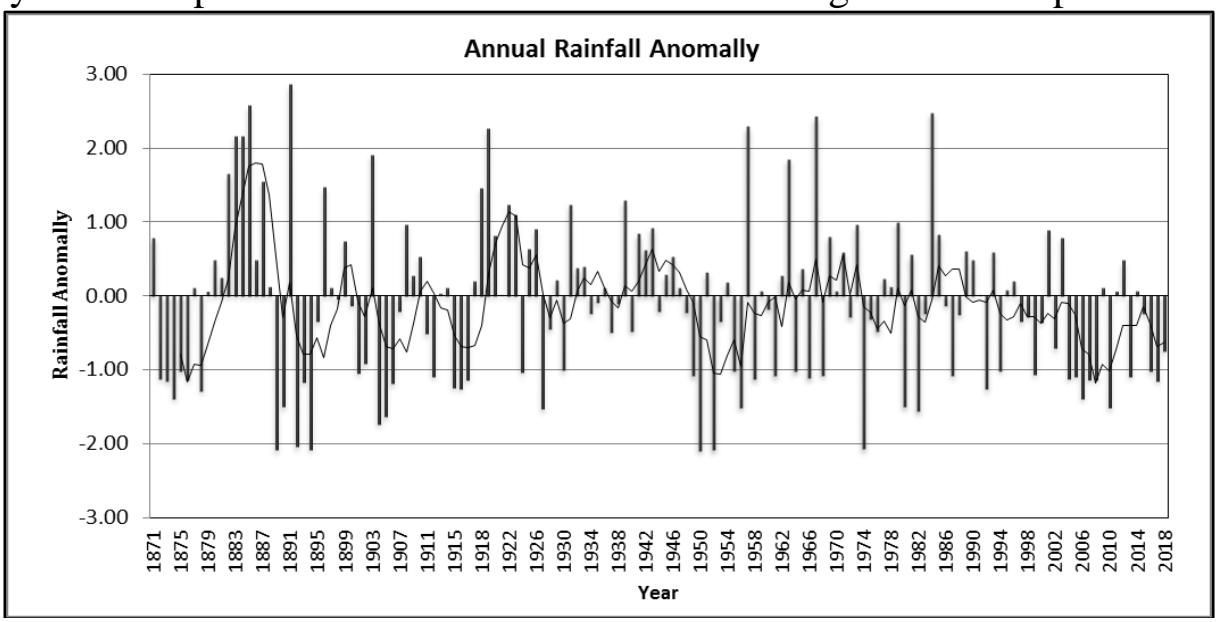

Fig.11 Rainfall Anomaly- Mannar

\subsection{Impacts of Drought on Agriculture}

In preparing a profile of drought impacts of a region, the knowledge of occurrence and intensity of droughts is significance, since not only it shapes the cropping pattern but also the socio-economic conditions of the region provide the guidelines about the drought effect. The impact assessments begin by identifying direct consequences of drought, such as affected families due to crop losses or reduced crop yields, livestock losses, and reservoir depletion. These direct outcomes can then be traced to social effects, such as the forced sale of the household assets or land, dislocation, or physical and mental stress (Ribot,1996), increase of food prices, unemployment, migration, and disaster relief programs. The drought affected place increasing social pressure on human many aspects and societal vulnerability to drought this often results in a decreased resilience of individual communities and an increased dependence on government. Fig.11, show the drought affected persons in 2019 in Mannar District.

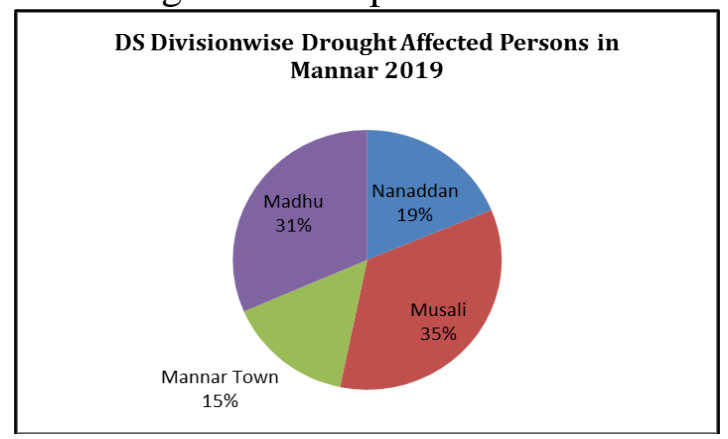

Fig.11 Drought Affected Person in Mannar-2019 
There are two main cropping seasons in cultivation. The 'Maha' or major wet season crop is usually grown during the period from October to February, while 'Yala' or minor season crop is cultivated during the period from March to August. The SIM \& NEM seasons rainfall is the source of water for cultivation in study area. In 2015, about 15408 hectares of paddy had cultivated under major irrigation scheme similarly about 3226 hectares under minor scheme. Only 54 hectares had cultivated under rain fed due to consecutive filature of monsoon. The paddy cultivation extent has been varying year to year (Table-VII) based on the availability water.

There are eleven major irrigation tanks in the district of Mannar. Giants tank' capacity of water is 31500 acre feet and the irrgable area is 9,890 hectares. Periyamadhu (5780 acre feet), Velimaruthamadhu (2766 acre feet),Viyaththikulam (1760 acrefeet),Kurai Tank (2062acrefeet), Mullikulam (1500 acrefeet), Adambankulam (580 acrefeet), Maruthamadhu (410 acrefeet), Periyapandivirichan (2816acrefeet), Thadchanamarutha Madhu (1945 acrefeet) and Akathimurippu (8588 acre feet) (Statistical Branch,2019). Paddy sown extent in 2016/17 under major and minor irrigation tanks are given in Table-VII. Manthai west and Nanadan DS divisions have higher extent of sown area compare with other DSD in the district under major scheme. However, the rain-fed cultivation area is reduced by 30hec.in the drought year of 2016/2017. The department of Irrigation and agrarian service granted permission to cultivate 20:1 ratio in 2018 based on the availability of water, which mean if a famer having 20 acres of paddy land, authority permitted to cultivate only one acre out of twenty. This ratio has further changed in 2019 as $24: 1$.

Table-VII Paddy Sown Extent by D.S.Division-2016/2017

\begin{tabular}{|l|r|r|r|r|}
\hline D.S.Division & $\begin{array}{c}\text { Major } \\
\text { Irrigation }\end{array}$ & $\begin{array}{c}\text { Minor } \\
\text { Irrigation }\end{array}$ & Rain fed & \multicolumn{1}{c|}{ Total } \\
\hline Mannar Town & 1932 & 0 & 0 & 1932 \\
\hline Mantai West & 3866 & 815 & 0 & 4681 \\
\hline Madhu & 772 & 1049 & 30 & 1851 \\
\hline Nanaddan & 3537 & 664 & 0 & 4202 \\
\hline Musali & 1483 & 422 & 0 & 1905 \\
\hline Total & 11590 & 2951 & 30 & 14571 \\
\hline
\end{tabular}

Source; Stastical Branch, District Secreteriat Mannar 2018

During the drought years of 2016, 2017, 2018 and 2019, these tanks' water had declined by 36-41percent due to consecutive negative departure of rainfall. The irrigable fields are fully dependent on these tanks' water. However inadequate water supply remarkably affects the crop production and yield. About 33percent of the cropped area even in the irrigated fields were either partially or fully damaged. In 2016 December, irrigation water availability was reported by the department of irrigation $23.3 \%$. Water scarcity in rain fed fields was much more severe and it is lead to crop losses or reduction of yield or avoids cultivation. Fig.12 shows the Maha and Yala crop yield reduction during drought years. It is estimated that, over 68 percent of the minor irrigation tanks had completely dried up which affected the wildlife habitat and ecosystem in many places in Mannar particularly Vankalai, Silavathurai,Musali, Kokkupadayan, Kondachi, Koolankulam,Periyanochikulam Pallatan Kulam , Poonochikulam, Panikkapettan Kulam, veppankulam, Sinna Attimoddai Kulam, Sinna Attimoddai Kulam, Uyilankulam, Adampan, Marichukkaddi, and Mullikulam villages.

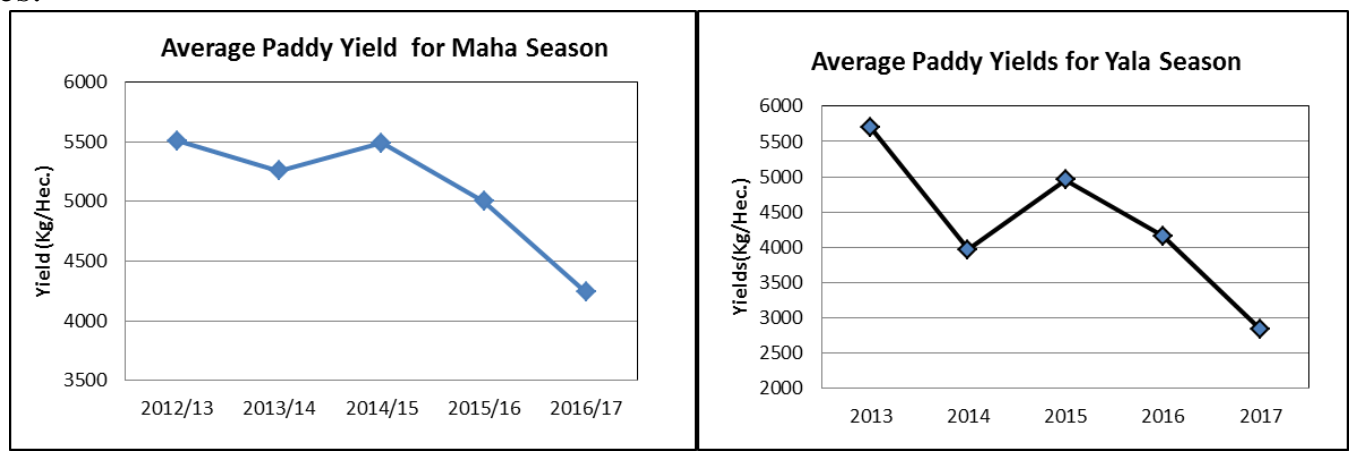

Fig.12 Average Paddy Yields for Maha and Yala Season (2012-2017) 
More than 52 percent of the well, the water level declined considerably. In the year 2013 (720mm) and 2014 $(971 \mathrm{~mm})$ rainfall was significantly lower and erratic than year $2012(1067 \mathrm{~mm})$ as a result in 2013/2014 Maha paddy shown extent remarkably declined as 5313 hectares, in the previous year of 2012/2013 it was about 15663 hectares and in 2015/2016 was 18698 (Statistical Branch, Kachcheri, Mannar-2018).

During the drought famers and others have been adopting various adjustments. In the dry zone of Sri Lanka, farmers have been adopting agricultural and non-agricultural based lifetime adjustments to reduce the drought vulnerability. Ancient settlers had constructed major and minor irrigation tanks and reservoirs in the dry zone for the agricultural development aim to improve rural livelihood and sustainability. After independence, the irrigated area increased significantly through various water resource development and colonization Programme in the dry zone. Farmers in the surveyed area have been following various methods of pre and post cultivation adjustments to drought or dry spells. They adopted different cropping mechanisms, in order to reduce their vulnerabilities to long dry spells and drought. Farmers choose the drought resistance crops for cultivation, local kind of millets and others and cultivate the subsidiary food crops, groundnuts or vegetable with supplement irrigation. They also reduce the cultivating area based on the availability of water or irrigation department together with agrarian service centre granting permission for possible irrigable area for cultivation. During the households' survey, the respondents were asked to mention the steps they have taken, if any, to overcome the hardships created by drought in 2016, 2017, 2018 \& 2019. Most of the poor farmers $(68 \%)$ have reduced their food consumption due to crop loss by drought. The affected households have adjusted both the quality and quantity of the foods consumed. Some farmers have utilized their stored paddy seeds $(12 \%)$. Most (63\%) have borrowed money from others or getting loan from banks with mortgage of jewellery and found difficulty in repay. Not only the farmers but also casual daily labourers were affected. They sold much of their household assets, such as animals, bicycles, jewellery. Famers who living in the coastal areas have been involving fishing activities (Vankalai, Silavathurai, Peruvelikkulam, and Vidataltivu etc.). Many of the male adults, mainly from villages in Adampan, Murungan, Mullikulam, Tharapuram, Mannar, Erukkalampiddy migrated to Colombo and Middle East countries in the hope of finding casual work. Some parents send their children as domestic servants to other places. There were fewer $(02 \%)$ working as mason, carpenter, labourer $(08 \%)$ in the construction section in Mannar, Vankalai and other places. Some are postponed their social arrangements such as marriage and other celebrations.

\subsection{Conclusion}

The district Mannar is one of the least rainfalls receiving areas in Sri Lanka which leads to higher rainfall variability and more frequent drought. The long-term average annual rainfall shows the decreasing tendency, particularly in recent epochs were found higher negative anomalies of rainfall, as a results frequent occurrence droughts or dry spells have been occurred. The rainfall anomaly results reveal that the probability of drought occurrence is $\mathrm{P}=0.320$. Though, in the recent epoch of $1991-2018$, higher number of droughts occurred than the any other epochs and the epochal probability of occurrence is increased as $\mathrm{P}=0.40$.

Drought is not a rapid onset hazards compare with other natural hazards but creating vast impact on agriculture, economy, water resource, environment, ecosystem and society. Farmers responded existing tanks has not been properly renovated (including de-silting) for more than four decades. Consequently, comprehensive drought management plan is required in controlling the disastrous effects of drought and also helping the people to evolve drought preparedness plan to reduce their impacts. the proper short term and long-term drought management plan and strategies should be practiced with people participation to reduce the impacts. Drought preparedness planning has become a widely accepted tool for governments at all levels to reduce the risks of future events. Drought plans contains three basic strategies: a) Drought Monitoring and an Early Warning System, b) Risk Assessment, c) Mitigation and Response. Appropriate water conservation, land use planning and drought management practices are required to mitigate the impacts. Introduce rain-water harvesting, increase capacity of water in the tank, adopt irrigation efficiency, reduce evaporation, introduce drought resistance crops, discouraging water intensive crops, encouraging sprinkler and drip irrigation systems, practicing alternate land use, conservation of water in soil, increase ground water recharge, optimum use of water, reduce the runoff, management crop land, and efficient water management, etc. can be assisted for long-term drought proofing in the study area. 


\section{References}

Balachandiran,S. (1975). An Assessment of Drought Months in Sri Lanka, Unpublished M.Sc. thesis, Dept. of Geography, University of Birmingham, UK.

Cabrinha,V. and F.E. Santo, (2000). Drought Tendencies in Mainland Portugal, Early Warning Systems for Drought Preparedness and Drought Management (Eds. D.A.Wilhite, M.V. K. Sivakumar \& D.A.Wood), World Meteorological Organization, Switzerland, 149-159.

Department of Social Service, (2002). Revised Record of the Department of Social Service, February 2002, Colombo.

Disaster Management Centre, (2012). Hazard profile of Sri Lanka, Colombo: Ministry of Disaster Management, Vidya Mawatha, Colombo 07.

Disaster Management Centre, (2019). Drought Situation Report-Sri Lanka, $5^{\text {th }}$ October 2019, Ministry of Public Administration and Disaster Management, Colombo.

Domros,M. 1(974). The agro climate of Ceylon. Franz Steiner Verlag, Wiesbaden.

Edwards D.C. and TB.McKee, (1997).Characteristics of $20^{\text {th }}$ century drought in the United States at multiple time scales. Climatology Report:97-2,Colorado State University, Fort Collins, Colorado.

FAO \& WFP.( 2017). Crop and food supply assessment mission to Sri Lanka, special report.

Fernando, T.K. and Chandrapala, L., 1995.Climate Variability in Sri Lanka, paper presented at International Symposium on Climate in Asia- Pacific, University of Brunei Darussalam.

Gunawardhana L.M.A.P. and Lal Mervin Dharmasiri, (2015). Drought Hazard and Managing Its Impacts through the Disaster Management Approach: A Study in the North Central Province of Sri Lanka, International Research Symposium, Rajarata University of Sri Lanka, 333-343.

Guttman, N.B.,(1998): Comparing the Palmer drought index and the Standardized Precipitation Index. Journal of the American Water Resources Association, 34(1):113-121.

Herath H.M.R.C. et.al. (2015). Analysis of Standard Precipitation Indices to Identify for Drought Condition in 2015, Sri Lanka Journal of Meteorology, Colombo, 1, 20-31.

Jameson,H. (1931). The Southwest monsoon drought over Ceylon. Meteorological Magazine, 66(783):58-61.

Madduma Bandara, C.(1983). Effect of drought on the livelihood of peasant families in the Dry Zone of Sri Lanka: A study on the Mahapothana Korale in the North Central Province. Climatological Notes, Tsukuba, Japan, 61-76.

Manesha Sathya Vimukthini , S. and Premalal, K.H.M.S., (2015). Develop Drought Monitoring in Sri Lanka Using Standard Precipitation Index (SPI), Sri Lanka Journal of Meteorology,1,64-71.

McKee, T. B., N. J. Doesken, and J. Kleist, (1993). The relationship of drought frequency and duration to time scales. Preprints, Eighth Conf. on Applied Climatology, Anaheim, CA, Amer. Meteor. Soc., 179-184.

McKee,T.B., Doesken, N.J., Kleist, J., (1995). Drought monitoring with multiple time scales. In: Proceedings of the 9th Conference on Applied Climatology, Dallas, TX, America. Meteorol. Soc. 233-236.

National Drought Mitigation Center U.S., (2008). Drought, the National Oceanic and Atmospheric Administration (NOAA).

Palmer,W. (1965). Meteorological Drought, U.S. Weather Bureau, Washington, D.C. Research Paper No. 45.

Prasanna, R.P.I.R. (2018). Economic Costs of Drought and Farmers' Adaptation Strategies: Evidence from Sri Lanka, Sri Lanka Journal of Economic Research (SLJER), 5(2), 61-79. 
Rajenram, K. (2005). Spatial and Temporal Profiles of the Occurrence of Droughts in Sri Lanka, Paper presented to 10th International Conference on Sri Lanka Studies, held 16th -18th Dec. 2005, Organized by the Research Centre for Social Science, University of Kelaniya, Sri Lanka.

Ravi Shah, (2015).Tayeb Raziei, Bhram Saghafian. Ana Paulo Lois Pereira Isabella Bordi, 2009).

Ruchira Lokuhetti1 et.al. 2(017). Drought Monitoring for Sri Lanka: Spatial Extent and Temporal Evolution during the 2016-17 Drought, IRENE, Colombo, Sri Lanka ,13-15, 1-7.

Sinha Ray, K.C. (2000). Role of Drought Early Warning Systems for Sustainable Agricultural Research in India, Early Warning System for Drought Preparedness and Drought Management, (eds. Donald A. Wilhite, K.Sivakumar \& Deborah A. Wood), World Metrological Organization, Switzerland, 117-129.

Sirinanda, K.U., (1984). A study of the climatic water balance analysis of the incidence of drought in Sri Lanka. 4555.

Sirinanda,K.U. (1975). Pattern of drought in the dry zone of Sri Lanka : A study of Water Balance Climatology. Ceylon Geographer, 21:33-41.

Statistical Branch, (2018). Statistical Hand book-Mannar, District Secretariat, Mannar .

Subrahmanyam,V.P. (1967). Incidence and Spread of Continental Drought, WMO/IHD Report No.2,WMO, Geneva.

Sugirtharan, M.et al. (2016). Impact of drought condition on the ecosystem of the Mannar District, Sri Lanka: A Case study, International Research Journal of Earth Sciences,4 (4), 29-34.

Tennakoon, M.U.A.(1986). Drought hazard and rural development: A study in precipitation of and adjustment to drought, Central Banka of Sri Lanka, Colombo.

Thennakoon, M., (1993). Drought and Farmer. Colombo: Central Bank of Sri Lanka.

Wikkramatileke,W.A.R. (1963).Southeast Ceylon: trend and problems in agricultural settlements, Dept. of Geography, Univ. of Chicago, Research paper 83, Chicago.

Wilhite, D.A. and Mark,D. Svoboda, (2000). Drought Early Warning Systems in the Context of Drought Preparedness and Mitigation, (Edited D.A.Wilhite,M.V.K.Sivakumar \& D.A.Wood), 1-16.

Wilhite, D.A., (2000), Drought as a natural hazard: Concepts and definitions. Droughts: A Global Assessment, D.A Wilhite, Ed., Routledge, 3-18.

Wilhite,D.A.,andG.H.Michael.(1987). Understanding the drought phenomenon, the role of definitions. Pages 1-27 in planning for drought toward a reduction of social vulnerability. (Eds. Donald Wilhite and Willam Easterling with Deborah, A. Wood). Westview Press/Boulder and London. 